\title{
THE STATE OF LIPID METABOLISM IN PATIENTS WITH ASPIRIN ASSOCIATED POLYPOUS RHINOSINUSITIS
}

\author{
Ivanna Koshel \\ Department otolaryngology \& head and neck surgery \\ Ivano-Frankivsk National Medical University \\ 2 Halytska str., Ivano-Frankivsk, Ukraine, 76018 \\ ivannakoshel@gmail.com
}

\begin{abstract}
Nowadays it is observed the wide prevalence of polypous rhinosinusitis, associated with intolerance to aspirin. From today positions the main principle of pathogenesis is in presence of "genetic block" of constitutive cyclooxigenase - the node enzyme of metabolism of arachidonic acid that leads to its active accumulation. It leads to the disorder of lipid metabolism and conditions the necessity to study its biochemical features.

Aim of research. To study biochemical parameters of the lipid exchange in patients with chronic polypous rhinosinusitis, associated with intolerance to acetylsalicylic acid by determination of the main metabolites.

Materials and methods. The results of laboratory examination of 20 patients with aspirin associated polypous rhinosinusitis are presented in the article. The control group included 7 practically healthy donors. There were studied the level of arachidonic acid in condensate of exhaled air, arachidonic, linoleic, eicosapentaenoic acids, phospholipids, malonic dialdehyde and oxide modification of protein in the blood serum.

Results. There were determined the changes of lipid exchange, which essence is in increase of the level of arachidonic acid in condensate of exhaled air and blood serum that leads to the decrease of the content of its main predecessors - linoleic and eicosapentaenoic acids and also phospholipids. The increase of arachidonic acid content stimulates the processes of peroxidation and leads to the increase of malonic dialdehyde content and oxide modifications of protein. The features of biochemical disorders testify to the proinflammatory direction of lipids metabolism.

Conclusions. The received data confirm the hypothesis of "genetic block" of arachidonic acid metabolism as the main pathogenetic link of polypous rhinosinusitis, associated with intolerance to aspirin, and allow clearly interpret the clinical image and the features of clinical course.
\end{abstract}

Keywords: aspirin associated polypous rhinosinusitis, cyclooxigenase, arachidonic acid, lipid exchange.

\section{Introduction}

The problem of pathogenesis, diagnostics and treatment of chronic polypous rhinosinusitis (CPRS) gained the special acuteness in last decades and became the one of topical problems of the modern medicine, both Ukrainian and European ones [1,2]. This group of diseases that is related to the fast spread ones has a tendency to progressive, relapsing course. At the modern stage the conception about the inflammatory origin of CRS is generally accepted [3]. From pathogenetic point of view it is the chronic relapsing inflammatory disease of the upper respiratory tracts that is attended with diffuse infiltration of all mucosa layers by eosinophilic granulocytes, and the lumen of the nasal cavity is filled with slime that contains a lot of eosinophils [4]. The inflammatory process remains even at the absence of significant clinical manifestations. The chronic RS with polyposis of nose that is characterized with eosonophilic inflammation is clinically attended with intolerance to acetylsalicylic acid in $25-65 \%$ of cases $[5,6]$. The nose polyps take place in $40-80 \%$ of patients with hypersensitivity to aspirin, and hypersensitivity takes place in $15-49 \%$ of patients with polyposis the aspirin $[6,7]$. The frequency of intolerance to aspirin in healthy people is $1 \%$ [8]. Hypersensitivity or intolerance to acetylsalicylic acid is explained for today by non-immunologic mechanisms, because it is not possible to determine the sensitization to this preparation. Taking into account that immunologic (allergic) mechanisms of aspirin hypersensitivity are not proved and the causes of disorders of arachidonic acid metabolism are not finally explained, they are found for today in taking aspirin and other NAIP that lead to the disorder of arachidonic acid (AA) metabolism [9]. That is why this disease is defined for today as «Aspirin-Exacerbated Respiratory Disease» that is exacerbation of the chronic disease of respiratory tracts, conditioned by aspirin [10]. But even the one dose of aspirin or oth- 
er non-steroidal preparations leads to the abrupt worsening of clinical course of already existent pathology, so the disorder of arachidonic acid metabolism with starting of the whole pathogenetic chain in patients appears without taking these preparations. That is why the study of mechanisms of development of aspirin associated polypous rhinosinusitis is a topical task.

From the positions of today the understanding of ethiopathogenesis aspirin associated polypous rhinosinusitis is connected with the change of arachidonic acid metabolism and is related to the group of metabolic diseases (MD) [10-12]. The principal position of pathogenesis is in presence of its node link that is genetically determined defect of the main enzyme of unsaturated fatty acids metabolism, especially arachidonic one - constitive cyclooxygenase - COG1 [13, 14]. As a result of blocked metabolism, arachidonic acid is accumulated in organism [15]. It is known, that the high concentrations of the free fatty acids activate NADPH-oxidase by activation of C protein kinase and activate the formations of free radicals. They initiate lipid peroxide oxidation (LPO) in membranes, development of oxidative stress that is characterized with accumulation of LPO toxic products, oxidative modification and injury of molecules of proteins and DNA [16]. At accumulation of hydroperoxides, unsaturated aldehydes, malonic dialdehyde and other toxic products of lipid peroxidation there are observed the disorders of metabolic processes: inhibition of activity of glycolysis and oxide phosphorylation, synthesis of protein and nucleic acids, disorders of the different enzyme processes [16].

Many scientists are agreed that the polypous growth is based on proinflammatory reaction in nasal epithelium, provoked by the free radical oxidation [17-19]. But the role of these processes in pathogenesis of polypous growth in general and especially in patients with aspirin intolerance were not studied systematically and that is why are not finally elucidated [20,21]. But the necessary condition of treatment on the principle of pathogenesis intervention is a deciphering of biochemical phenotype of disease that is the information about injured links of metabolism, all biochemical mechanisms that favor the development of pathological process. It is naturally, that on this base only it is possible to intervene in the disease pathogenesis purposefully. The aforesaid became a precondition for this research.

\section{Aim of research}

To study the features of lipid metabolism in patients with aspirin associated nasal polyposis by determination of the level of the main unsaturated fatty acids and their metabolites.

\section{Materials and methods of research}

The research included 20 patients, $24-57$ years old (mean age was 45,7 $\pm 0,85$ ) with diagnosis "chronic polypous rhinosinusitis, associated with intolerance to aspirin", who were on stationary treatment in ENT-department of the regional clinical hospital of Inano-Frankivsk city during 2015. Control included 7 somatically healthy donors, $20-50$ years old $(42,4 \pm 1,16)$.

Fatty acid composition of the blood serum was determined by the method of capillary gas-liquid chromatography. Identification of chromatographic peaks was realized using individual standard solutions of methyl ethers of the fatty acids. Registration and processing of chromatograms were carried out using computer with HP Chem Station software. The content of linoleic (18:2, $\omega-6)$, eicosapentaenoic (20:5, $\omega-3)$ and arachidonic (eicosatetraenoic) $(20: 4, \omega-6)$ acids fractions was determined.

The collection of condensate of exhaled air for determination of AA level was carried out using apparatus ECoScreen (Erich JAEGER GmbH). The quantitative levels of arachidonic acid were determined by IEA method using test-systems «Uscnscn Lifeife Sciencecience Inc. Wuhan» (USA).

Determination of phospholipids in the blood serum is based on interaction of phosphates after mineralization with ammonium molybdate at the presence of eikonogen. Extinction was measured at 630-690 nm against control on spectrophotometer SP 2000. The standard and control samples were set synchronously. Phosphorus concentration was determined by formula:

The analysis of lipids peroxide oxidation (LPO) products - malonic dialdehyde (MDA) was realized on the base of determination of TBA-active products by incubation of samples with thiobarbituric acid, extraction of the products of reaction by butanol and spectrophotometric detection of the colored complex on spectrophotometer SP 2000. 
The analysis of products of proteins peroxide oxidation - proteins oxidative modifications (PPM) is based on interaction of oxidized amino acid remains with 2,4-dinitrophenol hydrazine with creation of derivatives that have the typical spectrum of absorption. Aldehyde and ketone derivative of the neutral character were registered at $370 \mathrm{~nm}$ and the ones of the main character - at $430 \mathrm{~nm}$ of spectrophotometer SM 2000.

For assessment of the distinctions between groups the univariate disperse analysis was realized with the further use of Tukey criterion of the plural comparisons at the value level 0,05 [22].

\section{Results of research}

The results of our research demonstrated the reliable increase of the level of arachidonic acid in condensate of exhaled air and blood serum in patients with aspirin associated nasal polyposis comparing with control (Table 1).

Table 1

Level of main metabolites of lipid metabolism

\begin{tabular}{ccc}
\hline Metabolite name & Control & Studied group \\
\hline AA in condensate of exhaled air (\%) & $1,5 \pm 0,3$ & $5,0 \pm 0,6^{*}$ \\
AA in blood serum (\%) & $4,69 \pm 0,27$ & $16,99 \pm 0,17^{*}$ \\
Linoleic acid (\%) & $29,63 \pm 1,63$ & $18,24 \pm 3,2^{*}$ \\
Eicosapentaenoic (\%) & $18,57 \pm 1,94$ & $3,26 \pm 0,74^{*}$ \\
Phospholipids (mmol/l) & $3,96 \pm 0,08$ & $1,24 \pm 0,02^{*}$ \\
Malonic dialdehyde (nmol/ml) $_{\text {POM }_{370} \text { (mmol/g of protein) }}$ & $2,77 \pm 0,26$ & $4,1 \pm 0,15^{*}$ \\
POM $_{430}$ (mmol/g of protein) & $3,47 \pm 0,09$ & $4,93 \pm 0,16^{*}$
\end{tabular}

Note: *-statistically significant difference between groups is present $(p<0,05)$

In fatty-acid spectrum of condensate of exhaled air in patients with hypersensitivity to aspirin its content increases by 5,0 $\pm 0,6 \%$ comparing with $1,5 \pm 0,3 \%$ in control, in blood serum - up to $16,99 \pm 0,17 \%$ comparing with $4,69 \pm 0,27 \%$ in control. The differences between groups are statistically significant.

AA metabolic predecessor is linoleic acid. The study of fatty-acid composition of the patients' blood serum indicates the reliable decrease of linoleic acid quantity to $18,24 \pm 3,2 \%$ comparing with 29,63 $\pm 1,63 \%$ in control (Table 1). Eicosapentaenoic acid is also predecessor of arachidonic or eicosatetraenoic one. It was detected the reliably abrupt decrease of its level in patients of studied group to $3,26 \pm 0,74 \%$ comparing with $18,57 \pm 1,94 \%$ in control (Table 1).

The membrane phospholipids are the one of main sources of AA in organism. Our studies demonstrated that in healthy people the level of phospholipids corresponds to the value $3,96 \pm 0,08 \mathrm{mmol} / \mathrm{l}$. In patients with hypersensitivity to aspirin it is reliably decrease in more than three times that is 1,24 $\pm 0,02 \mathrm{mmol} / \mathrm{l}$ (Table 1).

At increase of the level of arachidonic acid the formation of free radicals is activated and the intensity of processes of peroxide oxidation or peroxidation of lipids and proteins grows. The LPO intensity can be testified by concentration of manolic dialdehyde in the blood serum. According to our data, MDA concentration in the blood serum of healthy people is $2,77 \pm 0,26 \mathrm{nmol} / \mathrm{ml}$, at aspirin associated polypous rhinosinusitis it increases to $4,1 \pm 0,15 \mathrm{nmol} / \mathrm{ml}$ (Table 1).

The intensity of proteins peroxidation can be testified by concentration of protein oxidative modifications in the blood serum. In healthy people of control group the level of POM products (aldehyde and ketone derivatives) in the blood plasma is: $\mathrm{POM}_{370}-3,47 \pm 0,09 \mathrm{mmol} / \mathrm{g}$ of protein, $\mathrm{POM}_{430}-1,93 \pm 0,04 \mathrm{mmol} / \mathrm{g}$ of protein. Our studies demonstrated the reliable increase of concentration of products of proteins oxidative modification in the bloods plasma of patients with aspirin associated polypous rhinosinusitis: $\mathrm{POM}_{370}$ - to $4,93 \pm 0,16 \mathrm{mmol} / \mathrm{g}$ of protein, $\mathrm{POM}_{430}$ - to $6,81 \pm 0,94 \mathrm{mmol} / \mathrm{g}$ of protein (Table 1). 
So, the results of the study of patients with polyposis, associated with intolerance to aspirin, demonstrated the abrupt increase (almost in 4 times) of arachidonic acid level in patients, decrease of the level of its metabolic predecessors (linoleic and eicosapentaenoic acids), decrease of the free phospholipids content. The significant increase of the level of LPO and POM products was observed.

\section{Discussion of the results of research}

According to the modern views, the principle position of pathogenesis of aspirin associated polypous rhinosinusitis is in genetically determined defect of the node enzyme of arachidonic acid metabolism - constitutive cyclooxigenase - COG1 (Fig. 1), [11, 13]. In previous works we proved the decrease of COG1 expression in mucosa of nasal cavity and polyps in patients with polypous rhinosinusitis, associated with intolerance to aspirin, using the methods of immunohistochemistry [14].

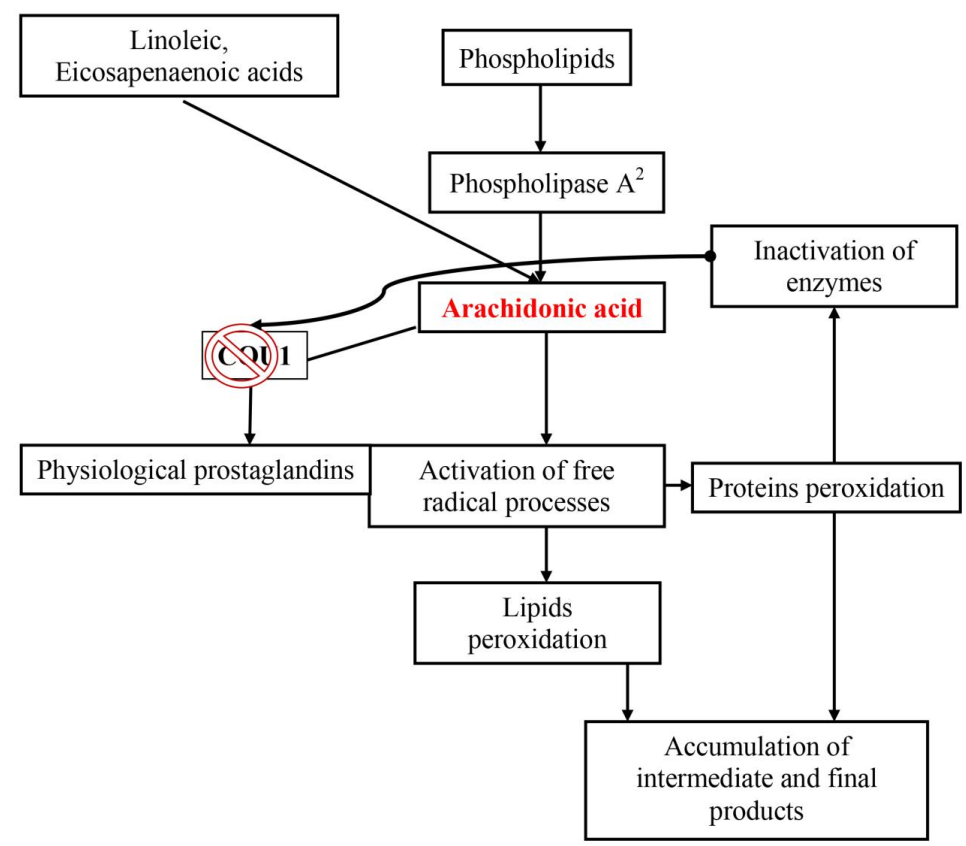

Fig. 1. Metabolism of arachidonic acid

The decrease of COG1 expression naturally leads to the active accumulation of arachidonic acid, because it is a substrate of constitutive COG (Fig. 1). The results of our research demonstrated the reliable increase of arachidonic acid level in condensate of exhaled air in patients with polyposis, associated with intolerance to aspirin to 5,0 $\pm 0,6 \%$ comparing with 1,5 $\pm 0,3 \%$ in norm and in the blood serum to $16,99 \pm 0,17 \%$ comparing with $4,69 \pm 0,27 \%$ in norm.

The decrease of constitutive COG function and AA accumulation lead to the search for the possible "alternate" ways of its metabolism and stimulate all its possible directions. The one of most important and early is accumulation of products that do not take part in metabolism that is the ones that are higher than "genetic block" (Fig. 1). We elucidated that the increase of AA content logically leads to the decrease of the level of predecessors, necessary for its synthesis, especially, linoleic acid that is metabolic predecessor of AA of the derivatives of $\omega-6$ class. It was detected the reliable decrease of the quantity of linoleic acid to $18,24 \pm 3,2 \%$ in patients comparing with $29,63 \pm 1,63 \%$ in control. Eicosapentaenoic acid is in fact also the final predecessor of arachidonic or eicosatetraenoic one but of the derivatives of $\omega-3$ class. It was detected the reliable abrupt decrease of its level in patients to $3,26 \pm 0,74 \%$ comparing with $18,57 \pm 1,94 \%$ in control (Table 1).

As it is known, the membrane phospholipids are the one of main sources of AA in organism. They are the substrate for phospholipases, especially phospholipase $\mathrm{A}_{2}$ as the result of which action AA is released from phospholipids (Fig. 1). Our studies demonstrated that in healthy people the phospholipids level corresponds to the value 3,96 $\pm 0,08 \mathrm{mmol} / 1$. In patients with hypersensitivity to aspirin it reliably decreases more than in three times and is $1,24 \pm 0,02 \mathrm{mmol} / \mathrm{l}$ (Table 1). So, the ex- 
cessive accumulation of AA leads, according to the principle of reverse connection, to the decrease of phospholipids (predecessors) content in the blood serum and, correspondingly, the decrease of activity of processes of its release.

At the disorder of arachidonic acid metabolism there takes place its inclusion in the other metabolic processes, especially free radical ones - lipids peroxide oxidation or peroxidation (LPO) by cyclooxigenase way (Fig. 1). The manolic dyaldehyde (MDA) is created in significant quantity, its concentration in the blood serum can testify about LPO intensity. According to our data, MDA concentration in the blood serum of healthy people is $2,77 \pm 0,26 \mathrm{nmol} / \mathrm{ml}$, at aspirin associated polypous rhinosinusitis it increases to $4,1 \pm 0,15 \mathrm{nmol} / \mathrm{ml}$ (Table 1).

The free radical processes manifest their injuring effect not only related to the lipids but also to the proteins (Fig. 1). It is known, that all enzymes that provide the infinite diverse link of metabolic and regulatory processes are proteins. The products of such reactions are the proteins oxidative modifications (POM). In healthy people the level of POM products (aldehyde and ketone derivatives) in the blood plasma is: $\mathrm{POM}_{370}-3,47 \pm 0,09 \mathrm{mmol} / \mathrm{g}$ of protein, $\mathrm{POM}_{430}-1,93 \pm 0,04 \mathrm{mmol} / \mathrm{g}$ of protein. Our studies demonstrated the reliable increase on concentration of products of proteins oxidative modification in the bloods plasma of patients with aspirin associated polypous rhinosinusitis: $\mathrm{POM}_{370}$ - to $4,93 \pm 0,16 \mathrm{mmol} / \mathrm{g}$ of protein, $\mathrm{POM}_{430}$ - to $6,81 \pm 0,94 \mathrm{mmol} / \mathrm{g}$ of protein (Table 1).

So, the results of the study of patients with polyposis, associated with intolerance to aspirin, demonstrated the abrupt increase (almost in 4 times) of arachidonic acid level in patients, decrease of the level of its metabolic predecessors of both derivative of $\omega-6$ - linoleic acid and of $\omega-3$ class - eicosapentaenoic one. It was also detected the decrease of free phospholipids content - the main source of AA in organism. The significant increase of AA level leads to the activation of free radical processed and significant increase of LPO and POM products.

The high arachidonic acid level and activation of lipids and proteins peroxidation is attended with accumulation of intermediate and final toxic products that cause metabolic intoxication of organism (Fig. 1). The expressed intoxication is typical for the clinical course of aspirin associated nasal polyposis [5]. Aggression of free radicals relative to the proteins leads to the change of their physical-chemical properties. At that the enzymes can lose their catalytically active groups that lead to the disorder of enzyme activity and metabolic processes. Such mechanism can take place at the secondary disorder of synthesis of enzymes, responsible for arachidonic acid metabolism (Fig. 1).

Modified proteins are not restored but destructed by proteolytic degradation. At the same time it must be taken into account that the decrease of activity of proteolysis enzymes is attended with the increase of the level of oxidatively modified proteins in the cell. It favors deceleration of proteolysis and apoptosis processes in such cells. As it is known, deceleration of apoptotic death, especially of eosinophils is the one of node moments of pathogenesis of productive process at eosinophilic nasal polyposis $[4,6]$.

\section{Conclusions}

1. In patients with aspirin associated with aspirin associated polypous rhinosinusitis was observed the significant increase of AA content in the blood serum and condensate of exhaled air that reliably exceeds the normal indices.

2. The increase of AA level leads to the decrease of the level of its main metabolic predecessors comparing with control: linoleic, eicosapentaenoic acids and phospholipids.

3. The activation of "alternate" ways, especially the free radical processes of AA metabolism leads to the growth of malonic dialdehyde, $\mathrm{POM}_{370}, \mathrm{POM}_{430}$ comparing with the control group as the result of COG1 block.

4. The revealed biochemical features in patients with aspirin associated polypous rhinosinusitis testify to the proinflammatory directionality of lipids metabolism that is the one of factors that favors the continuous-progredient course of disease, development of intoxicating syndrome and condition the expedience of the search for the methods of correction.

5. The revealed changes of lipid metabolism prove the hypothesis of "COG1 genetic block" as the main pathogenetic link of aspirin associated polypous rhinosinusitis. 


\section{References}

[1] Zhuravl'ov, A. S., Lupyr, A. V., Mishhenko, O. M., Kocyura, L. P (2014). Kliniko-epidemiologichni osoblyvosti obstezhennya hvoryh napolipoznyj rinosinusyt. Journal of Ear, Noseand Throat Diseases, 3, 65-66.

[2] Fokkens, W., Lund, V., Mullol, J. (2012). European position paper on rhinosinusitis and nasal polyps 2012. EPOS 2012, 50, 329.

[3] Zavadskij, A. V., Zavadskij, N. V., Zavadskaya, E. A. (2011). K patogenezu polipozanosa. Journal of Ear, Noseand Throat Diseases, 5, 61-62.

[4] Zavads'kij, A. V., Zavads'kij, N. V. (2011). E'ozinofily i rol'e'ozinofil'nogovospaleniya v patogenezepolipozanosa. Journal of Ear, Nose and Throat Diseases, 5, 2-7.

[5] Batra, P. S., Tong, L., Citardi, M. J. (2013). Analysis of comorbidities and objective parameters in refractory chronic rhinosinusitis. The Laryngoscope, 123, S1-S11. doi: 10.1002/lary.24418

[6] Stevens, W., Buchheit, K. Cahill, K. N. (2015). Aspirin-Exacerbated Diseases: Advances in Asthma with Nasal Polyposis, Urticaria, Angioedema, and Anaphylaxis. Current Allergy and Asthma Reports, 15 (12). doi: 10.1007/s11882-015-0569-2

[7] Erdogan, T., Karakaya, G., Kalyoncu, A. F. (2015). Comorbid diseases in aspirin-exacerbated respiratory disease, and asthma. Allergologia et Immunopathologia, 43 (5), 442-448. doi: 10.1016/j.aller.2014.07.008

[8] Wojtczak, A., Skrętkowicz, J. (2015). Hypersensitivity to acetylsalicylic acid. WiadLek, 68 (2), 193-197.

[9] Simon, R. A., Dazy, K. M., Waldram, J. D. (2015). Aspirin-exacerbated respiratory disease: characteristics and management strategies. Expert Review of Clinical Immunology, 11 (7), 805-817. doi: 10.1586/1744666x.2015.1039940

[10] Krouse, H. J., Krouse, J. H. (2015). Samter'sTriadto Aspirin-Exacerbated Respiratory Disease: Historical Perspectiveand Current Clinical Practice. ORL Head Neck Nurs, 33 (4), 14-18.

[11] Koshel, I. V., Dudiy, P. F., Ryzhyk, V. M. (2010). Aspirynovatriada: novi poglyady na etiopatogenez i diagnostyku [Aspirintriad: newoutlookontheetiopathogenesisanddiagnostics]. Ultrasound perinatal diagnostics, 30, 153-154.

[12] Makowska, J., Lewandowska-Polak, A., Kowalski, M. L. (2015). Hypersensitivity to Aspirin and other NSAIDs: Diagnostic Approach in Patients with Chronic Rhinosinusitis. Current Allergy and Asthma Reports, 15 (8). doi: 10.1007/s11882-015-0552-y

[13] Popovych, V. I., Kovalchuk, L. E., Erstenyuk, H. M., Ryzhyk, V. M., Koshel, I. V. (2009). Aspirynovatriada, yak metabolichne zahvoryuvannya [Aspirintriada smetabolic disease]. Journalofear, nose and throatdiseases, 2, 76-86.

[14] Koshel, I. V., Bahriy, N. M., Zabolotna, D. D. (2014). Riven' ekspresii konstytutyvnoi cyklooksigenazy $\mathrm{v}$ tkanynah porozhnynynosa u pacientiv z riznym typom nazal'nogo polipozu [Level of expression of constitutive cyclooxygenase in tissues of nasal cavity for patient with the different type of nasal polyposis]. Rhinology, 3, 21-30.

[15] Popovych, V. I., Ostrovskyy, M. M., Varunkiv, O. I., Koshel, I. V. (2012). Pat. № 100487. Sposib diagnostyky aspirynovoyi giperchutlyvosti u khvorykh na bronkhialnu astmu shlyakhom vyznachennya funktsionalnogo stanu metabolizmu arakhidonovoyi kysloty [Method of aspirin hypersensitivity diagnosis in patients with asthma by identifying the functional state of the metabolism of arachidonic acid] A61B 10/00, G01N 33/50. a201200631; declareted: 20.01.2012; published: 25.12.2012, Byul. № 24.

[16] Ganong, V. F. (2002). Fiziologiya lyudyny. Lviv: BaK, 784.

[17] Topal, O., Kulaksızoglu, S., Erbek, S. S. (2014). Oxidative stress and nasal polyposis: Does it affect the severity of the disease? American Journal of Rhinology and Allergy, 28 (1), 1-4. doi: 10.2500/ajra.2014.28.3963

[18] Bozkus, F., San, I., Ulas, T. et. al. (2013). Evaluation of total oxidative stress parameters in patients with nasalpolyps. Otorhinolaryngol Ital, 33 (4), 248-253.

[19] Jeanson, L., Kelly, M., Coste, A., Guerrera, I. C., Fritsch, J., Nguyen-Khoa, T. et. al. (2011). Oxidative stress induces unfolding protein response and inflammation in nasal polyposis. Allergy, 67 (3), $403-412$. doi: 10.1111/j.1398-9995.2011.02769.x

[20] Dytyatkovs'ka, E. M. (2011). Stan perekisnogo okislennyal ipidiv u hvorih na polinoz. Rhinology, 3, 11-17.

[21] Shiyan, S. P. (2016) Kliniko-biohimichneo bhruntuvannya antyoksidantnoi terapii u hvorih na polipoznirino synusyty. Kiev, 129.

[22] Lapach, S. N., Chubenko, A. V., Babych, P. N. (2000). Statisticheskie metody v medico-biologicheskih issledovaniyah s isspolzovaniem Exel [Statistical methods in biomedical research using Exel]. Kyiv: Morion. 